TITLE:

\title{
SUPPOSED EFFECTS OF THE COLD WEATHER OF THE WINTER 1962-63 UPON THE INTERTIDAL FAUNA IN THE VICINITY OF SETO
}

\author{
AUTHOR(S): \\ Tokioka, Takasi
}

\section{CITATION:}

Tokioka, Takasi. SUPPOSED EFFECTS OF THE COLD WEATHER OF THE WINTER 1962-63 UPON THE INTERTIDAL FAUNA IN THE VICINITY OF SETO. PUBLICATIONS OF THE SETO MARINE BIOLOGICAL LABORATORY 1963, 11(2): 415-424

ISSUE DATE:

1963-12-31

URL:

http://hdl.handle.net/2433/175332

RIGHT: 


\title{
SUPPOSED EFFECTS OF THE COLD WEATHER OF THE WINTER 1962-63 UPON THE INTERTIDAL FAUNA IN THE VICINITY OF SETO ${ }^{13}$
}

\author{
TAKASI TOKIOKA
}

Seto Marine Biological Laboratory

With Plates XVIII-XX and 2 Text-figures

In the end of last winter, persons were surprised at so great accumulations of whitish empty shells of the tropical sea urchin, Echinometra mathaei (BLAINVILLE), at some parts of the north shore near our laboratory, these shells were then broken into pieces after several rough weathers. From April to September, I paid several visits to Hatakezima, a reef near Ezura and the rocky shore around Tôsima Islet in the vicinity of Seto taking students of various colleges and biological institutes of some universities for biological field observations. Then I was aware that many of tropical or subtropical animals had quite disappeared or been much decreased in the intertidal zones of these places. The most impressive finding was the complete disappearance of Echinometra mathaei which had been one of the commonest animals occurring in the lower part of the intertidal zone on the offshore side in this vicinity. Actually this sea urchin had occupied, before last winter, up to nearly one third of the whole echinid population at that part of the intertidal zone. It does not seem that the whole echinid population has diminished the size, rather the niche of Echinometra seems to be taken by Anthocidaris crassispina (A. Agassiz). Echinostrephus aciculatus A. Agassiz occurs abundantly together with Anthocidaris in the studied places, but it is not likely that Echinostrephus took the place of Echinometra, as there were found unusually abundant empty shells, easily distinguishable by its greenish tint on the aboral side, and also many dying individuals of this sea urchin in the spring season. Evidently Echinostrephus belongs to the echinids of the warm water and its activity must be much oppressed during last winter. Echinometra is, however, not yet perished in this vicinity; actually it still survives, though it is now very scarce even in the sublittoral zone. Then, it is quite possible that the species increases steadily to the level of the population density maintained before the cold weather in last winter, if a long lasting cold weather is

1) Contributions from the Seto Marine Biological Laboratory, No. 408.

Publ, Sețo Mar, Biol, Lab., XI (2), 1963, (Article 26) 
not repeated in coming several years. Really observations made by Mr. YAMAsU of the Tamano Marine Biological Station and Mr. GHiselin of the Hopkins Marine Station on September 22 near the distal end of the cape (Text-fig. 1, Em) where the laboratory is situated revealed that a few individuals were lodging in crevices on walls of some tide pools. Thus, it seems to be a very interesting work to clear out in what way Echinometra invades the echinid fauna in the lower intertidal zone and regains its former positions, since this implies that

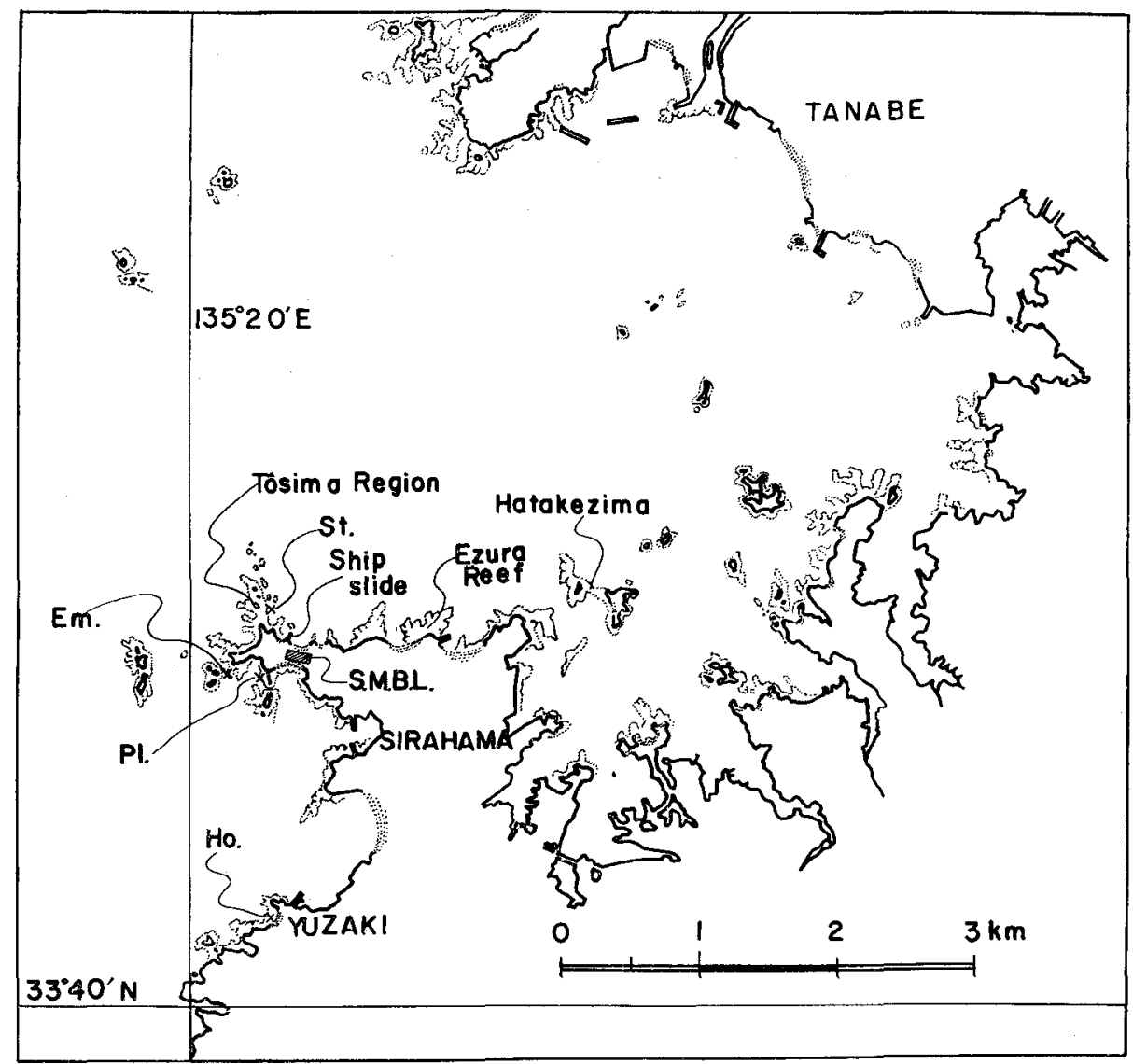

Text-fig. 1. Map of Tanabe Bay, showing the localities in the Vicinity of Seto. Em.Echinometra observed, Ho.-Holothuria leucospilota observed, Pl.-Planaxis observed, S.M.B.L.-Seto Marine Biological Laboratory, St.-Stephanoscyphus observed.

Echinometra may regain its former niche by chasing Anthocidaris crassispina out from it. Are there any kind of struggle between Anthocidaris and Echinometra for the acquisition of niche, or are there any differences in habit between these two sea urchins, which lead quite naturally to the restoration of Echinometra's niches and retreatment of Anthocidaris crassispina from there? To prepare for 
such future studies, it is indispensable to make exact records of the present state of the echinid population in the lower intertidal zone. Thus an ecinid census was attempted on June 23 at Hatakezima, when the water was $6 \mathrm{~cm}$ high above the low water mark at the lowest. One of the echinid colonies on the offshore side of Hatakezima (Ec. in Text-fig. 2) was thus chosen to see the composition of population in such circumstances (Plate XVIII). The colony is an area of about $10 \mathrm{~m}^{2}$ extending around a roundish elevation about $50 \mathrm{~cm}$ in dia-

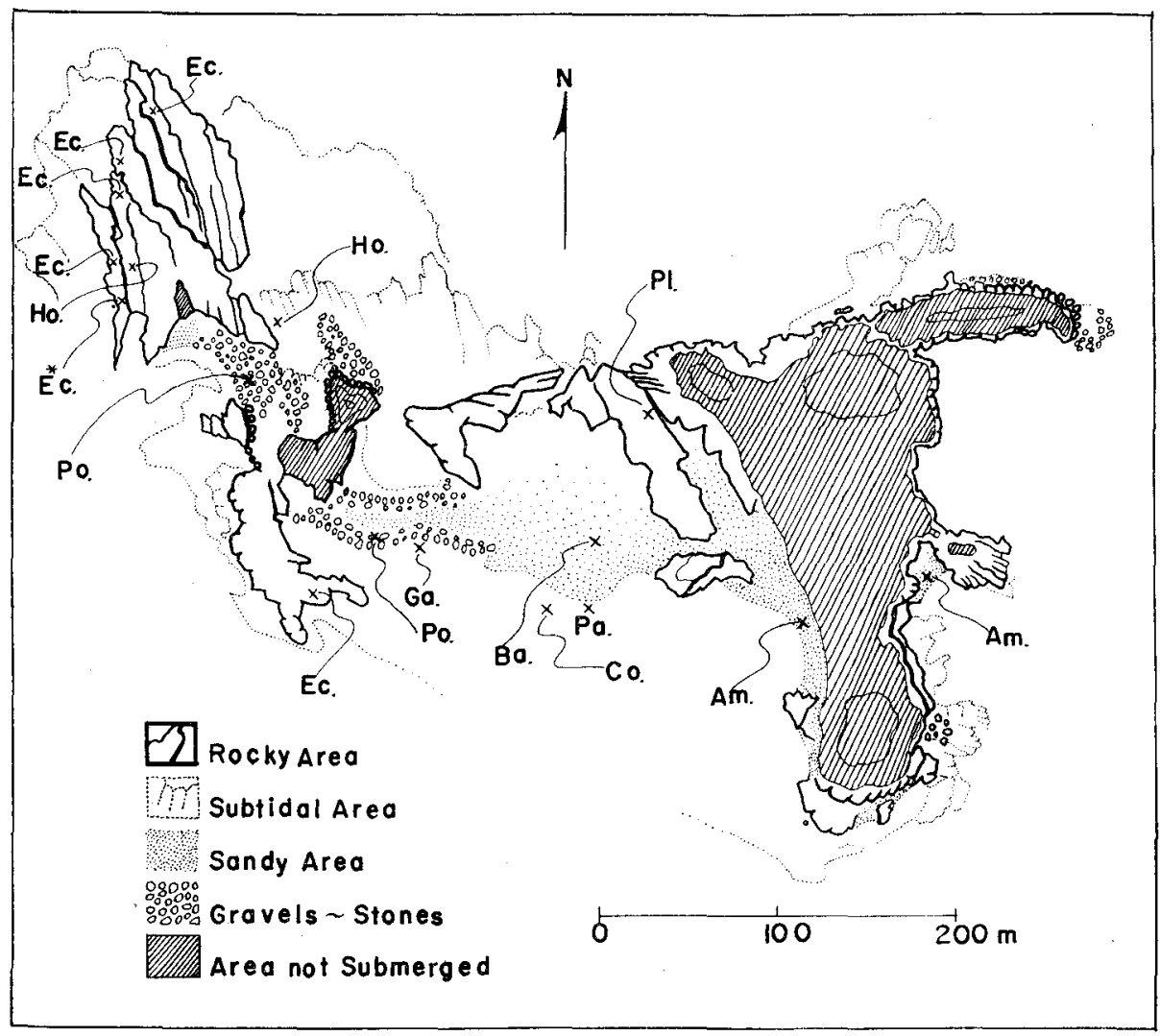

Text-fig. 2. Map showing the intertidal zones at Hatakezima. Am.-Amphidesma beach, Ba.-Balanoglossus field, Co.--Conomurex ground, Ec.-Echinid colony (* studied colony), Ga.-Gafradium observed, Ho.-Holothuria pool, Pa.-Paphia observed, P1.-Planaxis colony, Po.-Polycheira observed.

meter (Plate XIX) near the southwest corner of the northwest rocky shore $(* \mathrm{Ec}$. in Text-fig. 2), several centimeters above the low water mark and exposed only at spring tides, and furnished with abundant holes or concavities which respectively hold one to several sea urchins within. The area was divided into four sections by crossed ropes (Plates $\mathrm{XIX}$ and $\mathrm{XX}$ ), and the census was made in 
Table 1. Composition of an echinid colony at Hatakezima.

\begin{tabular}{|l|c|c|c|c|c|c|}
\cline { 2 - 7 } \multicolumn{1}{c|}{} & Section 1 & Section 2 & Section 3 & Section 4 & Total & Percent \\
\hline Echinostrephus aciculatus & 29 & 68 & 48 & 73 & 218 & 51.1 \\
\hline Anthocidaris crassispina & 38 & 70 & 44 & 54 & 206 & 48.2 \\
\hline Hemicentrotus pulcherrimus & 1 & & 1 & & 2 & 0.5 \\
\hline Pseudocentrotus depressus & 1 & & & & 1 & 0.2 \\
\hline
\end{tabular}

each section; the results are shown in Table 1.

Of other echinids, Diadema setosum (LESKE) was extremely decreased in the intertidal zone, too. But this might be caused by overfishing, as the gonad of this sea urchin is served as one of the sea foods in this region. Considerable numbers of individuals are still seen in the subtidal zone, and in autumn the population has recovered the density in some degree in various pools. Mespilia globulus (LinnaEus) which had been found rather commonly in the lower part of the intertidal zone was much decreased. Also, Toxopneustes pileolus (LAMARCK) and Tripneustes gratilla gratilla (Linnaeus) have been decreased remarkably; a few individuals of the former were met with near the low water mark in the Tôsima region, while the latter disappeared completely from the intertidal zone, although a few are still met with in the sublittoral zone. The decline of these two large-sized echinids is partly attributable to a collecting these as sea food. Stomopneustes variolaris (LAMARCK) which had been found in a small number along the low water mark on the offshore side of Hatakezima and the Tôsima region could not be found in any observations.

Of other echinoderms, the decrease of Holothuria leucospilota (BRANDT) in the vicinty is most remarkable. Before last winter, this had been seen quite commonly in shallow pools and shallow sublittoral zone of Hatakezima (Textfig. 2, Ho.), Ezura and Yuzaki (Text-fig. 1). But now, this can scarcely be seen in the first two localities. Only two individuals were found on June 23, three on July 22 and three on September 6 at Hatakezima and a single individual on June 27 near the ship slide of the laboratory (Text-fig. 1). In the Yuzaki district where the water temperature may be maintained a little higher because of the waste hot spring water pouring into there, the population of this holothurian is said to have dropped to about one third of the former size (after the observation made by Dr. Yamanouchi in September). Holothuria pervicax Selenka which had been much fewer than $H$. leucospilota in the intertidal zone was also decreased. Only a single specimen was observed on June 22 at Hatakezima. However, underwater observations made by Dr. R. Okuno of the Suma Aquarium of Kobe City and Mr. $\mathrm{C}_{\mathrm{H}}$. ARAgA of the aquarium of our laboratory show that 
these two holothurians are often met with in the sublittoral zone, especially this is true about $H$. pervicax. Polycheira rufescens (BRANDT) seems to be maintaining the former population density in this vicinity.

Other animals which seemed to be much affected by the cold weather were several mollusks. Of the sedentary bivalves, Saxostrea mordax (Gould) which had been sparsely found at the upper intertidal zone on the offshore side of Hatakezima and the rocky shore around Tôsima, all died out and the same with Chama (Pseudochama) retroversa Lischke in the lower intertidal zone in the vicinity. Mr. URA, the collector of the laboratory, mentions about the latter that he has never seen any living shells since this spring in this region but only the fresh white inner surface of right shells left attached to the rock surface. Gafrarium divaricatum (Gmelin), Paphia amabilis (Philippi), Amphidesma (Atactodea) striatum (GMELIN), and Pinctada martensii (Dunker), all remarkable warm water bivalves in this vicinity, do not seem to be much affected during last winter. Of the snails, the subtropical periwinkle Nodilittorina vilis (PHILIPPI), Nerita (Theliostyla) albicilla Linnaeus, and Drupa (Morulina) granulata (Duclos) are not affected by the cold weather of last winter; especially great numbers of the first species were found aggregated at small pools in the spray zone of the rocky shore near Tôsima on July 22. On the northern rocky shore of Hatakezima (Text-fig. 2, Pl.), there had been a notable colony of Planaxis sulcatus (BoRN) in the upper intertidal zone. This colony was completely perished by the cold. However, I could find a small number of this snail of a smaller size on the southern rocky shore near our laboratory on August 7 (Text-fig. 1, Pl.). Probably this place was being washed by water during low tides in winter and this might keep the snails from destruction. Conomurex luhuanus (Linnaeus) is one of the tropical strombid snails inhabiting in this vicinity, being found commonly near the low water mark at spring tides in the spring season. This snail must be affected by the cold to some extent, as the living specimens were scarcely met with in the exposed area at any low tides at least in last spring season. Its population in the subtidal zone seems to have increased with season and in September a considerable number of living specimens were brought into our aquarium.

In the Tôsima region, Stephanoscyphus racemosus KomaI, the scyphopolyp of Nausithoe punctata Kölliker, disappeared from tide pools, though it still survives on the surface of rocky cliffs or ledges in the subtidal zone in that area (Text-fig. 1, St.). In the same region, the decrease of nephtheid alcyonaceans in shallow subtidal zone is very striking, but I am not assured that this was caused by the cold in last winter. Mr. Araga suggests that the commensal sea anemone, Calliactis polypus (FORSKẢL), commonly found on shells harbouring the hermit crab, Dardanus haani RathBun, seems to be perished by the water of low temperature in last winter, as none of this actinian has been brought into 
our aquarium since last spring, and it is quite unusual that this sea anemone has disappeared from every tank of our aquarium.

The cold weather in winter will affect marine organisms by chilling sea water or directly in the intertidal zone while they are exposed. As to the first process, the low temperature itself, the duration of low temperature and the gradient at which the temperature drops are factors to be considered. In the present case about the animals in the inter-tidal zone, however, the second process must be taken as the leading factor. Then the fall of the temperature at the low tide is evidently most dangerous to intertidal organisms of the warm water nature. In last winter, there were nine periods when the effect of the cold weather with the extreme low atmospheric temperature below $10^{\circ} \mathrm{C}$ might be extended to the organisms inhabiting below $10 \mathrm{~cm}$ level above the low water mark :

1. November 29 to December 1 (lasted for 3 days)

2. December 10 to December 14 (lasted for 5 days)

3. December 26 to December 28 (lasted for 3 days)

4. December 31 (lasted for a day)

5. January 7 to January 13 (lasted for 7 days)

6. January 23 to January 29 (lasted for 7 days)

7. February 6 to February 11 (lasted for 6 days)

8. February 21 to February 27 (lasted for 7 days)

9. March 23 to March 26 (lasted for 4 days).

Of these, the fifth to the eighth occurred at intervals of seven to nine days seemed to be responsible for the destruction of those animals without notable tolerableness against chilling. Especially the sixth attack of the cold was considered to be nearly fatal, since low tides were repeated for seven days when both the atmospheric temperature and water temperature were lowest throughout last winter.

Before closing this note I want to express here my hearty thanks to Messrs. S. URA and S. SAKAI of our laboratory for their kind informations about the above-mentioned animals, to $\mathrm{Mr}$. Ch. ARAGA of the aquarium of the laboratory to whom I owe for most of underwater observations, and also to my son Takasi, Jr., for his help in making sea urchin census at Hatakezima. 
Table 2. Meteorological data for Nov. 18, 1962 to Apr. 22, 1963.

\begin{tabular}{|c|c|c|c|c|c|}
\hline Date & & $\begin{array}{l}\text { Time of } \\
\text { lowest water }\end{array}$ & $\begin{array}{c}\text { Level of } \\
\text { lowest water }\end{array}$ & $\begin{array}{c}\text { Minimum atmospheric } \\
\text { temperature. }\end{array}$ & $\begin{array}{c}\text { Water } \\
\text { temperature }\end{array}$ \\
\hline $\begin{array}{l}1962 \\
\text { Nov. } \\
1\end{array}$ & $\begin{array}{l}18 \\
19 \\
20\end{array}$ & $\begin{array}{l}3.54 \\
4.57 \\
6.15\end{array}$ & $\begin{array}{l}42 \mathrm{~cm} \\
57 \\
69\end{array}$ & $\begin{array}{c}11.0^{\circ} \mathrm{C} \\
7.6 \\
10.9\end{array}$ & $\begin{array}{l}21.22^{\circ} \mathrm{C} \\
20.80 \\
20.40\end{array}$ \\
\hline & $\begin{array}{l}21 \\
22 \\
23 \\
24 \\
25\end{array}$ & $\begin{array}{r}7.33 \\
21.39 \\
22.11 \\
22.39 \\
23.08\end{array}$ & $\begin{array}{l}75 \\
74 \\
60 \\
46 \\
34\end{array}$ & $\begin{array}{r}15.5 \\
10.7 \\
9.5 \\
5.0 \\
4.0\end{array}$ & $\begin{array}{l}19.80 \\
19.20 \\
19.26 \\
19.20 \\
19.40\end{array}$ \\
\hline & $\begin{array}{l}26 \\
27 \\
28 \\
29 \\
30\end{array}$ & $\begin{array}{r}23.36 \\
11.43 \\
0.05 \\
0.37 \\
1.11\end{array}$ & $\begin{array}{r}24 \\
79 \\
15 \\
9 \\
7\end{array}$ & $\begin{array}{r}8.9 \\
9.1 \\
12.3 \\
8.9 \\
8.0\end{array}$ & $\begin{array}{l}18.88 \\
18.40 \\
18.80 \\
17.80 \\
17.42\end{array}$ \\
\hline Dec. & $\begin{array}{l}1 \\
2 \\
3 \\
4 \\
5\end{array}$ & $\begin{array}{l}1.49 \\
2.30 \\
3.19 \\
4.16 \\
5.27\end{array}$ & $\begin{array}{r}9 \\
16 \\
27 \\
40 \\
53\end{array}$ & $\begin{array}{l}7.2 \\
8.4 \\
8.3 \\
3.1 \\
8.7\end{array}$ & $\begin{array}{l}17.84 \\
18.00 \\
17.00 \\
17.66 \\
17.00\end{array}$ \\
\hline 1 & $\begin{array}{r}6 \\
7 \\
8 \\
9 \\
10\end{array}$ & $\begin{array}{r}6.49 \\
20.59 \\
21.49 \\
22.34 \\
23.17\end{array}$ & $\begin{array}{r}62 \\
54 \\
33 \\
14 \\
0\end{array}$ & $\begin{array}{l}8.3 \\
4.7 \\
3.9 \\
3.5 \\
5.6\end{array}$ & $\begin{array}{l}16.06 \\
16.62 \\
17.40 \\
17.42 \\
18.00\end{array}$ \\
\hline & $\begin{array}{l}11 \\
12 \\
13 \\
14 \\
15\end{array}$ & $\begin{array}{r}23.59 \\
12.17 \\
0.39 \\
\mathbf{1} .21 \\
2.01\end{array}$ & $\begin{array}{r}-8 \\
74 \\
-11 \\
-\quad 8 \\
2\end{array}$ & $\begin{array}{r}7.4 \\
5.3 \\
3.4 \\
6.1 \\
10.3\end{array}$ & $\begin{array}{l}18.00 \\
16.26 \\
16.80 \\
17.24 \\
18.82\end{array}$ \\
\hline & $\begin{array}{l}16 \\
17 \\
18 \\
19 \\
20\end{array}$ & $\begin{array}{l}2.42 \\
3.24 \\
4.09 \\
5.02 \\
6.06\end{array}$ & $\begin{array}{l}14 \\
30 \\
47 \\
62 \\
75\end{array}$ & $\begin{array}{l}6.9 \\
6.2 \\
7.2 \\
4.6 \\
6.9\end{array}$ & $\begin{array}{l}17.42 \\
16.82 \\
17.28 \\
15.60 \\
17.64\end{array}$ \\
\hline & $\begin{array}{l}21 \\
22 \\
23 \\
24 \\
25\end{array}$ & $\begin{array}{l}20.52 \\
21.33 \\
22.09 \\
22.42 \\
23.15\end{array}$ & $\begin{array}{l}69 \\
54 \\
40 \\
25 \\
12\end{array}$ & $\begin{array}{l}7.9 \\
7.7 \\
4.9 \\
6.8 \\
3.5\end{array}$ & $\begin{array}{l}17.20 \\
16.22 \\
16.80 \\
16.42 \\
15.60\end{array}$ \\
\hline $\begin{array}{l}2 \\
2 \\
2 \\
2 \\
3 \\
3\end{array}$ & $\begin{array}{l}26 \\
27 \\
28 \\
29 \\
30 \\
31\end{array}$ & $\begin{array}{r}23.49 \\
12.03 \\
0.25 \\
1.02 \\
1.41 \\
2.22\end{array}$ & $\begin{array}{r}2 \\
80 \\
--6 \\
--9 \\
-6 \\
2\end{array}$ & $\begin{array}{r}7.2 \\
5.7 \\
9.0 \\
11.5 \\
13.3 \\
4.6\end{array}$ & $\begin{array}{l}16.42 \\
16.20 \\
16.40 \\
16.04 \\
16.02 \\
14.06\end{array}$ \\
\hline $\begin{array}{l}1963 \\
\text { Jan. }\end{array}$ & $\begin{array}{l}1 \\
2 \\
3 \\
4 \\
5\end{array}$ & $\begin{array}{r}3.08 \\
3.57 \\
4.56 \\
19.19 \\
20.30\end{array}$ & $\begin{array}{l}15 \\
32 \\
49 \\
61 \\
45\end{array}$ & $\begin{array}{l}3.2 \\
3.4 \\
4.5 \\
5.0 \\
1.4\end{array}$ & $\begin{array}{l}15.24 \\
14.62 \\
14.60 \\
12.60 \\
12.82\end{array}$ \\
\hline
\end{tabular}


Table 2 continued

\begin{tabular}{|c|c|c|c|c|}
\hline Date & $\begin{array}{l}\text { Time of } \\
\text { lowest water }\end{array}$ & $\begin{array}{l}\text { Level of } \\
\text { lowest water }\end{array}$ & $\begin{array}{c}\text { Minimum atmospheric } \\
\text { temperature }\end{array}$ & $\begin{array}{c}\text { Water } \\
\text { temperature }\end{array}$ \\
\hline $\begin{array}{r}\text { Jan. } \quad 6 \\
7 \\
8 \\
9 \\
10\end{array}$ & $\begin{array}{l}21.30 \\
22.22 \\
23.08 \\
23.51 \\
12.08\end{array}$ & $\begin{array}{r}27 \mathrm{~cm} \\
9 \\
-3 \\
-11 \\
78\end{array}$ & $\begin{array}{l}3.6^{\circ} \mathrm{C} \\
3.5 \\
3.5 \\
0.7 \\
3.5\end{array}$ & $\begin{array}{l}13.00^{\circ} \mathrm{C} \\
12.96 \\
12.20 \\
12.40 \\
12.60\end{array}$ \\
\hline $\begin{array}{l}11 \\
12 \\
13 \\
14 \\
15\end{array}$ & $\begin{array}{l}0.31 \\
1.09 \\
1.45 \\
2.20 \\
2.54\end{array}$ & $\begin{array}{r}-13 \\
-10 \\
-\quad 1 \\
12 \\
26\end{array}$ & $\begin{array}{l}4.8 \\
2.4 \\
0.5 \\
1.2 \\
3.0\end{array}$ & $\begin{array}{l}12.26 \\
10.24 \\
10.80 \\
11.60 \\
13.28\end{array}$ \\
\hline $\begin{array}{l}16 \\
17 \\
18 \\
19 \\
20\end{array}$ & $\begin{array}{r}3.26 \\
3.59 \\
4.40 \\
19.41 \\
20.45\end{array}$ & $\begin{array}{l}42 \\
58 \\
73 \\
68 \\
55\end{array}$ & $\begin{array}{r}-0.3 \\
1.1 \\
2.7 \\
1.9 \\
1.9\end{array}$ & $\begin{array}{l}11.88 \\
12.22 \\
12.00 \\
13.40 \\
11.20\end{array}$ \\
\hline $\begin{array}{l}21 \\
22 \\
23 \\
24 \\
25\end{array}$ & $\begin{array}{l}21.35 \\
22.16 \\
22.57 \\
23.35 \\
11.52\end{array}$ & $\begin{array}{r}39 \\
22 \\
7 \\
-6 \\
76\end{array}$ & $\begin{array}{r}3.2 \\
0.3 \\
-0.8 \\
-1.9 \\
-1.2\end{array}$ & $\begin{array}{r}10.48 \\
9.82 \\
10.88 \\
10.46 \\
10.22\end{array}$ \\
\hline $\begin{array}{l}26 \\
27 \\
28 \\
29 \\
30 \\
31\end{array}$ & $\begin{array}{l}0.13 \\
0.52 \\
1.30 \\
2.09 \\
2.50 \\
3.34\end{array}$ & $\begin{array}{r}-13 \\
-15 \\
-12 \\
-\quad 1 \\
15 \\
35\end{array}$ & $\begin{array}{l}0.5 \\
1.3 \\
0.2 \\
4.3 \\
3.5 \\
1.2\end{array}$ & $\begin{array}{r}10.02 \\
10.22 \\
10.60 \\
10.82 \\
11.84 \\
9.82\end{array}$ \\
\hline $\begin{array}{ll}\text { Feb. } & 1 \\
& 2 \\
& 3 \\
& 4 \\
& 5\end{array}$ & $\begin{array}{c}4.21,17.15 \\
18.41 \\
20.08 \\
21.20 \\
22.16\end{array}$ & $\begin{array}{l}56 \\
52 \\
42 \\
27 \\
13\end{array}$ & $\begin{array}{l}0.9 \\
1.9 \\
2.4 \\
2.1 \\
3.1\end{array}$ & $\begin{array}{r}9.82 \\
10.00 \\
10.82 \\
10.66 \\
10.88\end{array}$ \\
\hline $\begin{array}{r}6 \\
7 \\
8 \\
9 \\
10\end{array}$ & $\begin{array}{r}23.03 \\
23.42 \\
12.01 \\
0.19 \\
0.53\end{array}$ & $\begin{array}{r}2 \\
-5 \\
72 \\
-5 \\
0\end{array}$ & $\begin{array}{l}0.7 \\
3.9 \\
4.1 \\
4.6 \\
1.6\end{array}$ & $\begin{array}{l}11.00 \\
11.60 \\
12.22 \\
11.62 \\
11.20\end{array}$ \\
\hline $\begin{array}{l}11 \\
12 \\
13 \\
14 \\
15\end{array}$ & $\begin{array}{l}1.24 \\
1.52 \\
2.19 \\
2.44 \\
3.10\end{array}$ & $\begin{array}{r}7 \\
17 \\
31 \\
45 \\
60\end{array}$ & $\begin{array}{r}3.5 \\
2.4 \\
3.1 \\
2.0 \\
-0.6\end{array}$ & $\begin{array}{l}12.00 \\
11.42 \\
11.60 \\
12.80 \\
12.88\end{array}$ \\
\hline $\begin{array}{l}16 \\
17 \\
18 \\
19 \\
20\end{array}$ & $\begin{array}{l}16.51 \\
18.12 \\
19.46 \\
20.58 \\
21.50\end{array}$ & $\begin{array}{l}66 \\
65 \\
57 \\
42 \\
25\end{array}$ & $\begin{array}{l}3.7 \\
2.0 \\
3.0 \\
1.5 \\
2.9\end{array}$ & $\begin{array}{l}12.80 \\
12.24 \\
12.40 \\
12.60 \\
13.40\end{array}$ \\
\hline $\begin{array}{l}21 \\
22 \\
23 \\
24 \\
25\end{array}$ & $\begin{array}{r}22.37 \\
23.18 \\
23.56 \\
12.13 \\
0.34\end{array}$ & $\begin{array}{r}9 \\
-\quad 3 \\
-10 \\
52 \\
-10\end{array}$ & $\begin{array}{l}1.6 \\
3.1 \\
2.3 \\
4.5 \\
3.8\end{array}$ & $\begin{array}{l}12.64 \\
13.00 \\
13.20 \\
13.80 \\
13.80\end{array}$ \\
\hline $\begin{array}{l}26 \\
27 \\
28\end{array}$ & $\begin{array}{l}1.13 \\
1.50 \\
2.28\end{array}$ & $\begin{array}{r}-5 \\
9 \\
27\end{array}$ & $\begin{array}{l}2.4 \\
4.5 \\
3.9\end{array}$ & $\begin{array}{l}13.62 \\
12.80 \\
13.22\end{array}$ \\
\hline
\end{tabular}


Table 2 continued

\begin{tabular}{|c|c|c|c|c|c|}
\hline Date & & $\begin{array}{l}\text { Time of } \\
\text { lowest water }\end{array}$ & $\begin{array}{l}\text { Level of } \\
\text { lowest water }\end{array}$ & $\begin{array}{l}\text { Minimum atmospheric } \\
\text { temperature }\end{array}$ & $\begin{array}{c}\text { Water } \\
\text { temperature }\end{array}$ \\
\hline Mar. & $\begin{array}{l}1 \\
2 \\
3 \\
4 \\
5\end{array}$ & $\begin{array}{l}15.39 \\
16.40 \\
18.05 \\
19.48 \\
21.08\end{array}$ & $\begin{array}{l}38 \mathrm{~cm} \\
44 \\
48 \\
44 \\
34\end{array}$ & $\begin{array}{l}1.4^{\circ} \mathrm{C} \\
6.1 \\
8.0 \\
6.4 \\
2.8\end{array}$ & $\begin{array}{l}13.12^{\circ} \mathrm{C} \\
13.60 \\
13.82 \\
13.62 \\
12.80\end{array}$ \\
\hline & $\begin{array}{r}6 \\
7 \\
8 \\
9 \\
10\end{array}$ & $\begin{array}{r}22.06 \\
22.50 \\
23.27 \\
11.47 \\
0.00\end{array}$ & $\begin{array}{l}23 \\
15 \\
11 \\
62 \\
11\end{array}$ & $\begin{array}{l}1.6 \\
0.6 \\
1.7 \\
6.7 \\
6.1\end{array}$ & $\begin{array}{l}13.10 \\
12.86 \\
12.68 \\
12.40 \\
13.80\end{array}$ \\
\hline & $\begin{array}{l}11 \\
12 \\
13 \\
14 \\
15\end{array}$ & $\begin{array}{r}0.29 \\
0.56 \\
1.21 \\
14.05 \\
14.34\end{array}$ & $\begin{array}{l}15 \\
23 \\
33 \\
42 \\
44\end{array}$ & $\begin{array}{l}5.2 \\
6.8 \\
2.9 \\
4.4 \\
6.9\end{array}$ & $\begin{array}{l}12.68 \\
12.80 \\
12.08 \\
12.62 \\
13.46\end{array}$ \\
\hline & $\begin{array}{l}16 \\
17 \\
18 \\
19 \\
20\end{array}$ & $\begin{array}{l}15.09 \\
15.54 \\
17.01 \\
18.45 \\
20.18\end{array}$ & $\begin{array}{l}48 \\
53 \\
57 \\
57 \\
47\end{array}$ & $\begin{array}{r}11.0 \\
7.7 \\
1.6 \\
8.5 \\
7.0\end{array}$ & $\begin{array}{l}15.48 \\
14.20 \\
14.22 \\
14.00 \\
14.22\end{array}$ \\
\hline & $\begin{array}{l}21 \\
22 \\
23 \\
24 \\
25\end{array}$ & $\begin{array}{l}21.22 \\
22.13 \\
22.54 \\
23.34 \\
11.51\end{array}$ & $\begin{array}{r}33 \\
20 \\
9 \\
5 \\
34\end{array}$ & $\begin{array}{r}11.2 \\
9.5 \\
9.5 \\
7.9 \\
5.6\end{array}$ & $\begin{array}{l}15.62 \\
15.20 \\
15.18 \\
14.86 \\
13.24\end{array}$ \\
\hline & $\begin{array}{l}26 \\
27 \\
28 \\
29 \\
30 \\
31\end{array}$ & \begin{tabular}{r|}
0.13 \\
13.04 \\
13.44 \\
14.27 \\
15.14 \\
16.13
\end{tabular} & $\begin{array}{r}7 \\
14 \\
12 \\
15 \\
24 \\
36\end{array}$ & $\begin{array}{r}2.3 \\
6.9 \\
10.7 \\
9.8 \\
\\
3.5\end{array}$ & $\begin{array}{l}14.00 \\
14.22 \\
14.60 \\
15.42 \\
12.88 \\
14.62 \\
\end{array}$ \\
\hline Apr. & $\begin{array}{l}1 \\
2 \\
3 \\
4 \\
5\end{array}$ & $\begin{array}{l}17.35 \\
19.21 \\
20.46 \\
21.44 \\
22.27\end{array}$ & $\begin{array}{l}47 \\
49 \\
44 \\
38 \\
33\end{array}$ & \begin{tabular}{r|}
11.8 \\
10.0 \\
3.9 \\
11.4 \\
13.8
\end{tabular} & $\begin{array}{l}15.60 \\
15.42 \\
14.40 \\
15.26 \\
16.26\end{array}$ \\
\hline & $\begin{array}{r}6 \\
7 \\
8 \\
9 \\
10\end{array}$ & $\begin{array}{l}23.02 \\
23.33 \\
11.52 \\
12.16 \\
12.42\end{array}$ & $\begin{array}{l}32 \\
34 \\
43 \\
35 \\
30\end{array}$ & $\begin{array}{r}6.9 \\
14.5 \\
11.7 \\
8.1 \\
5.5\end{array}$ & $\begin{array}{l}17.06 \\
17.28 \\
16.04 \\
16.40 \\
14.40\end{array}$ \\
\hline & $\begin{array}{l}11 \\
12 \\
13 \\
14 \\
15\end{array}$ & $\begin{array}{l}13.07 \\
13.33 \\
14.04 \\
14.37 \\
15.22\end{array}$ & $\begin{array}{l}28 \\
27 \\
25 \\
35 \\
41\end{array}$ & $\begin{array}{r}5.4 \\
9.8 \\
13.4 \\
15.1 \\
15.8\end{array}$ & $\begin{array}{l}15.00 \\
15.20 \\
15.82 \\
16.62 \\
17.04\end{array}$ \\
\hline & $\begin{array}{l}16 \\
17 \\
18 \\
19 \\
20\end{array}$ & $\begin{array}{l}16.24 \\
17.56 \\
19.34 \\
20.46 \\
21.42\end{array}$ & $\begin{array}{l}49 \\
55 \\
52 \\
44 \\
35\end{array}$ & $\begin{array}{r}16.6 \\
19.9 \\
19.0 \\
16.9 \\
8.7\end{array}$ & $\begin{array}{l}17.60 \\
18.22 \\
18.18 \\
19.04 \\
17.88\end{array}$ \\
\hline & $\begin{array}{l}21 \\
22\end{array}$ & $\begin{array}{l}22.27 \\
23.09\end{array}$ & $\begin{array}{l}29 \\
27\end{array}$ & $\begin{array}{r}3.8 \\
13.9\end{array}$ & $\begin{array}{l}16.82 \\
17.08\end{array}$ \\
\hline
\end{tabular}




\section{EXPLANATION OF PLATES XVIII-XX}

Plate XVIII. Sight around the surveyed echinid colony.

Above-The laboratory is situated along the beach stretching on the picture for about $10 \mathrm{~mm}$ about $10 \mathrm{~mm}$ left from the end of the cape.

Below-The stand is $150 \mathrm{~cm}$ high and the pictures were taken by Takasi TokıokA, Jr., standing on it.

Plate XIX.

Above-Full sight of the colony; the left above is Section 1, the right above Section 2, the left below Section 3 , and the right below Section 4. The envelope at the centre, on a roundish elevation, is about $30 \mathrm{~cm}$ in length.

Below-Census is going on in Section 1. A part of Section 3 is seen below, and on the right parts of Sections 2 and 4 are seen.

Plate XX.

Above--Central part of the colony. The left above is Section 2, the left below Section 1, the right above Section 4, and the right below Section 3.

Below-Distributions of Echinostrephus aciculatus (crossed circle) and Anthocidaris crassispina (solid circle) in the area shown above. 
Publ. Seto Mar. Biol. Lab., XI, 2 (1963)
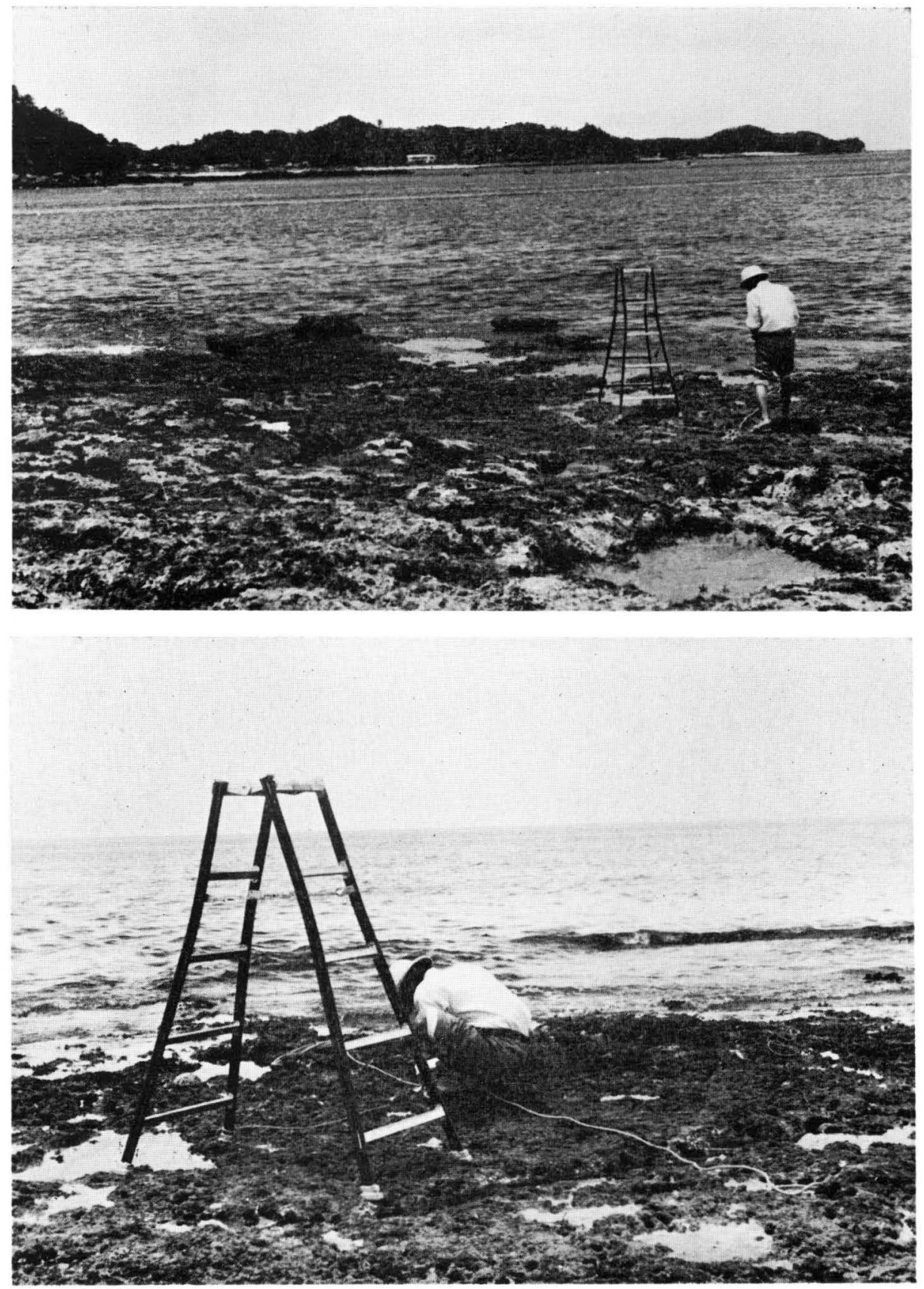

Takasi Tokioka: Supposed Effects of Cold Weather. 

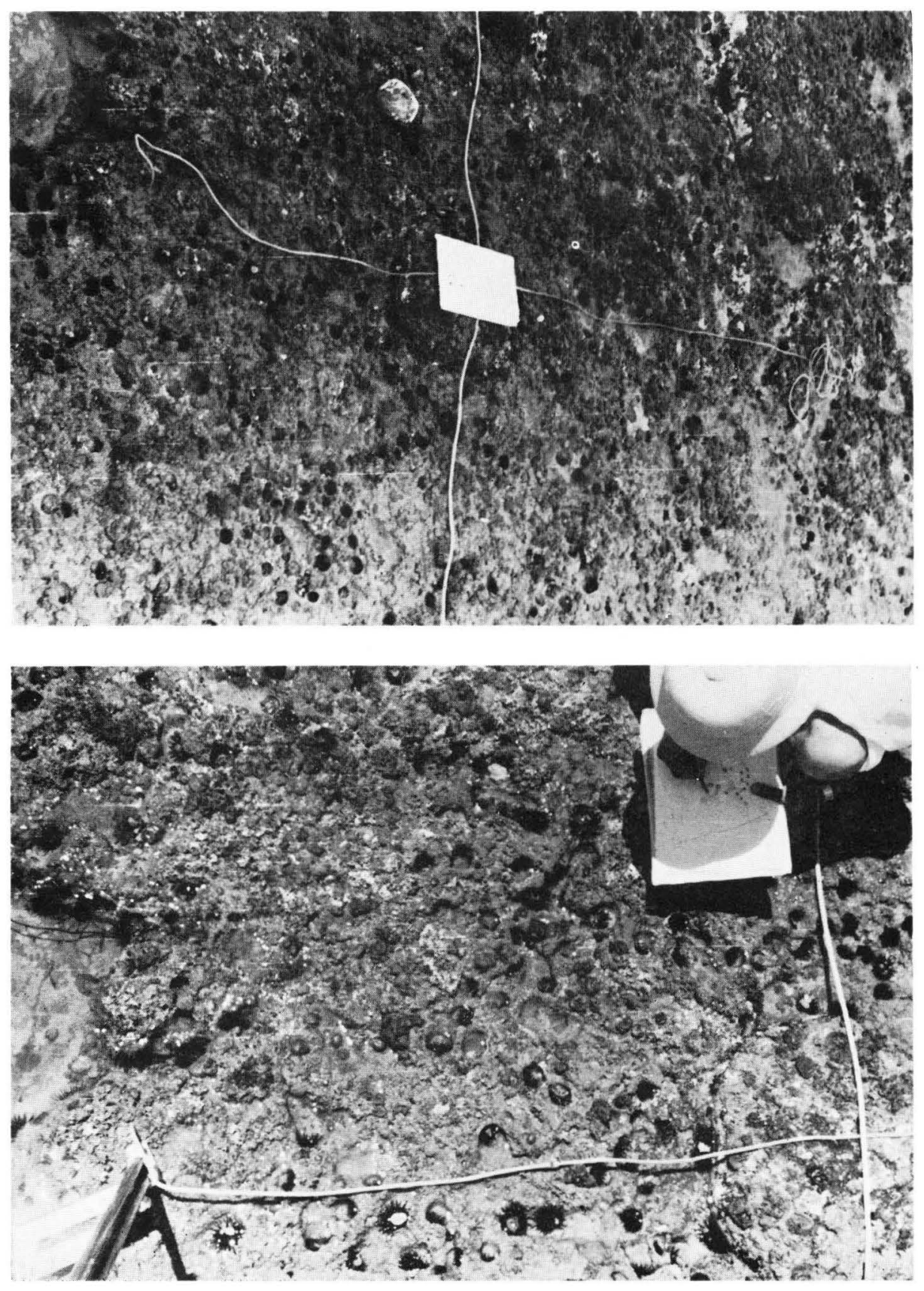

Takasi Tokioka: Supposed Effects of Cold Weather. 

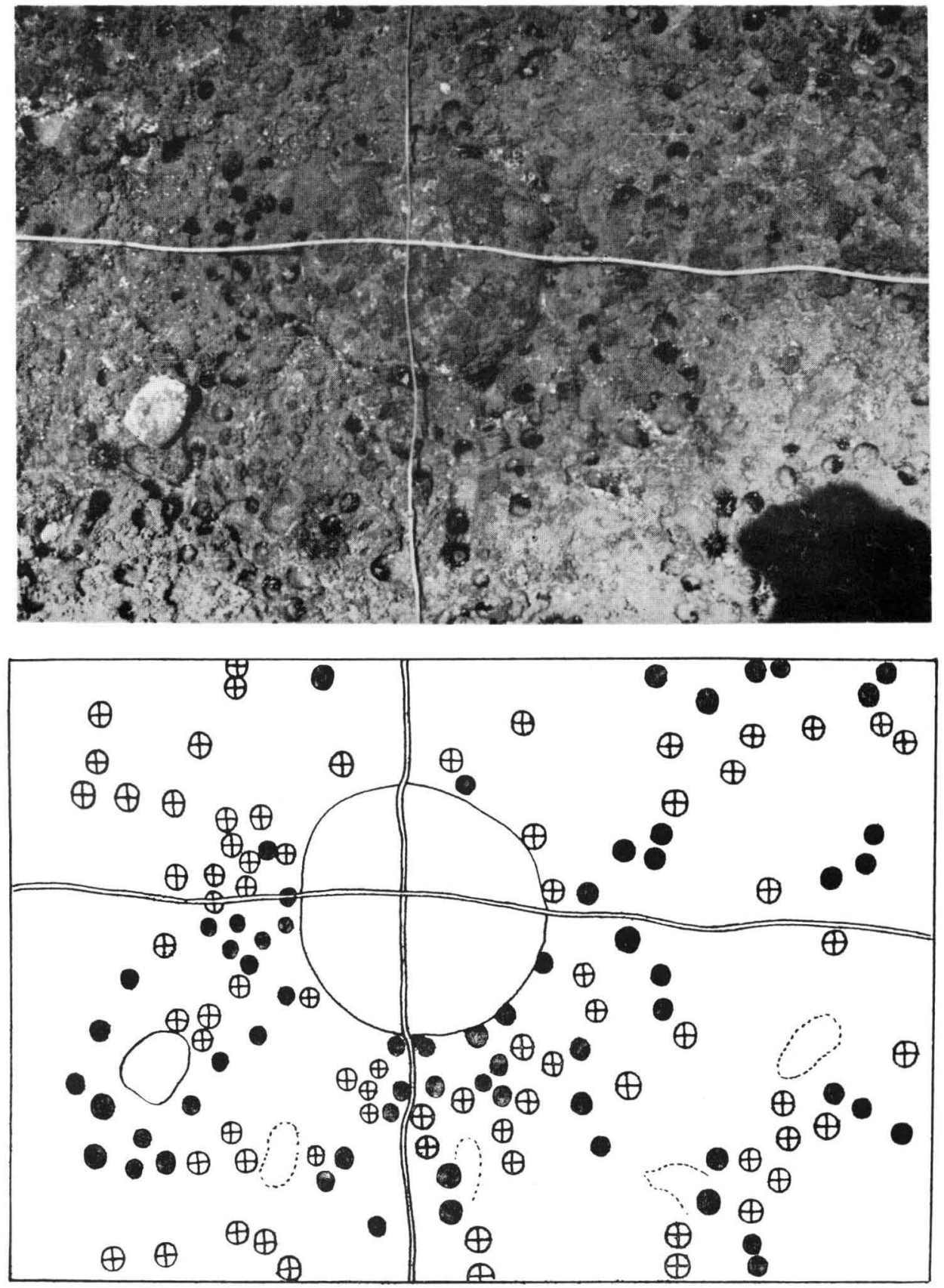

Takasi Tokioka: Supposed Effects of Cold Weather. 